Original Article

\title{
Emotionally Focused Couples Therapy and Spirituality
}

\author{
Merve Nurlu ${ }^{1}$
}

${ }^{1}$ Ph.D. Candidate, Marmara University, İstanbul,34722, Turkey, E-mail: mervenurlu89@gmail.com

\section{Corresponding author:}

Merve Nurlu

E-mail:

mervenurlu89@gmail.com

eISSN: $2458-9675$

Received: 11.02 .2020

Revision: 19.04.2020

Accepted: 27.04.2020

C) Copyright 2020

by Author(s)

\begin{abstract}
Emotionally focused therapy was created as a couples therapy approach and has become a frequently used therapeutic approach these days. This approach, theoretically based on the understanding that the attachment relationship observed between mother and child characterized by proximity seeking and separation anxiety resembles the relationship observed between couples, aims to turn unhealthy attachment relationships between couples into healthy ones. This process is realized by revealing the implicit and hidden emotions that cause problem situations to occur and gaining awareness about these emotions. Diff erent studies have shown spirituality to be a major factor both in forming and solving problem situations in therapy for couples who care about spiritual values. In particular, the meanings couples who attach importance to religious values attribute to marriage and the quality of the relations developed within this meaning can be handled within the framework of emotionally focused couples therapy. The purpose of this article is to explain how the therapy process proceeds when emotionally focused couples therapy is combined with spiritual values and to show which methods and techniques are used in the light of sample cases. In addition, the article aims to raise awareness on how to use this therapy approach, as it can be combined with Islamic elements, and investigates how to set an example in this regard. This study, which briefly introduces emotionally focused couples therapy, provides short examples of how to perform interventions while working with couples who seek counseling using religious or spiritual matters.
\end{abstract}

Keywords: Attachment, Romantic attachment, God attachment, Emotionally focused couples therapy, Spirituality

\section{Duygu Odaklı Çift Terapisi ve Maneviyat}

\section{Öz}

Duygu Odaklı Terapi bir çift terapisi yaklaşımı olarak oluşturulmuş ve günümüzde sıkça kullanılan bir terapi yaklaşımı olmuştur. Anne ve bebek arasındaki bağlanma ilişkilerinde görülen yakınlık ve huzur arayıșı ile ayrılma endişesi süreçlerinin bir benzerinin romantik çift ilişkilerinde de görüldüğü anlayışıyla teorik açıdan temellendirilen bu yaklaşımda amaç, çiftler arasındaki sağlıksız bağlanma ilişkilerini sağlıklı hale çevirebilmektir. Bu süreç problem durumlarının oluşmasına sebep olan örtük ve saklı duyguların ortaya çıkarılıp bu duygulara ilişkin farkındalıkların kazandırılmasıyla gerçekleşmektedir. Manevi değerlere önem veren çiftler ile yapılan terapide, hem problem durumunun oluşumunda hem de çözümünde maneviyatın büyük bir etken olduğu yapılan farklı çalıșmalarda görülmektedir. Özellikle dini değerlere önem veren çiftlerin evliliklerine atfettikleri anlam ve bu anlam çerçevesinde gelişen ilişkilerin niteliği Duygu Odaklı Terapi yaklaşımı çerçevesinde ele alınabilmektedir. Bu makalede amaç, Duygu Odaklı Terapi yaklaşımının manevi değerler ile birleștiğinde terapi sürecinin nasıl ilerlediği ile ilgili açıklamalarda bulunmak ve terapi yaklaşımının hangi yöntem ve tekniklerinin daha çok kullanıldığını örnek vak'alar eşliğinde göstermektir. Ayrıca İslami ögeler ile birleştirilebilecek bu terapi yaklaşımının nasıl kullanılabileceği konusunda bir farkındalık oluşturularak bu açıdan örnek teşkil etmesi istenmiştir. Bu çalışmada öncelikle Duygu Odaklı Çift Terapisi kısaca tanıtılmıș ve daha sonra dinsel veya manevi ögelerle danıșmaya gelen çiftlerle çalış1ırken müdahale yöntemlerinin nasıl olacağı ile ilgili kısa vak'a örneklerine yer verilmiştir.

Anahtar Kelimeler: Bağlanma, Romantik Bağlanma, Tanrı Bağlanması, Duygu Odaklı Çift Terapisi, Maneviyat

Citation: Nurlu, M. (2020). Emotionally focused couples therapy and spirituality. Spiritual Psychology and Counseling, 5, 237 - 250. https://dx.doi.org/10.37898/spc.2020.5.2.97 
Spirituality adds meaning to people's existence, sets moral standards for living, and enables humanity to connect with each other sincerely (Aponte, 2002). Spirituality as a whole adds meaning and purpose to interpersonal relations, describes the relationship between God and humans, sets the moral standards for living, and instills a sense of hope in people (Dansby, Hayes, \& Schleiden, 2017). In psychotherapy, significant positive relationships have been found for religion/spirituality with health, quality of life, social support, and the decreased presence of depressive symptoms (Pickard \& Nelson-Becker, 2011).

Spirituality is closely related to family and couples therapy because both spirituality and family/couples therapies have a relational basis and spirituality manifests itself the most when working with families and couples (Walsh, 2012). Therefore, the most important thing is not whether to integrate spirituality or sacredness into therapy when working with spiritual and religiously oriented clients but when and how to achieve this integration (Post \& Wade, 2009). Couples and family counselors also want to integrate spiritual content into their psychotherapy practice and seek ways to do this (Furrow, Johnson, Bradley, \& Amodeo, 2011).

Emotionally focused couples therapy, created by Johnson and Greenberg (1985) in the late 1980s, is one of the most used couples/family therapy approaches (LandauNorth, 2006). Although emotionally focused couples therapy was originally created for couples, it has also become used as an approach for individuals and families over time and has taken names such as emotionally focused family therapy and emotionally focused individual therapy (Johnson, 2019). When looking at the theoretical foundations of the emotionally focused therapy approach, they are seen to be based on the attachment theory developed by Bowlby $(1969,1973)$, which explains the attachment relationships that develop between a baby and caregiver (Gladding, 2015). In Bowlby's attachment theory, attachment relationships serve a vital purpose, and every baby has a biological tendency to maintain a close relationship with the caregiver. Although the need for a baby to be close to the caregiver is a biological predisposition, the quality of the relationship established between the baby and the caregiver ensures that the baby makes sense of love and support and whether the caregiver is reliable on the point of care and support (Bowlby, 1969, 1973). These representations also play a determining role in the relationships formed in adulthood (Kaya Balkan, 2009). Attachment relationships are formed with different people, and they continue to exist as a structure that does not change much (Allen, 2008).

\section{Emotionally Focused Couples Therapy}

Gurman and Fraenkel (2002) stated the emotionally focused therapy approach to be one of the first three approaches used in the field of couples therapy, and this is why the founders of the approach constantly strive to regulate the approach in terms of both content and the techniques used. 
Studies investigating the marital satisfaction and stress experienced in marriage have revealed the satisfaction felt and stress experienced to have a significant impact on both spouses' health and the functioning of the marriage. In addition, determining the importance given to close relationships, the causes of stress and tension in close relationships, and effective intervention methods and examining spouses' process of change, as well as studies on adult love and attachment have now been placed on solid scientific foundations (Johnson, 2017). Although the emotionally focused therapy approach appeared in the 1980s, it was created as a couple therapy approach focused on intrapsychic processes (Johnson \& Greenberg, 1985) and was based on vital and structural family therapy models instead of behavioral models (Simon, 2004).

\section{Romantic Attachment and God Attachment}

Weiss (1982) was first to state the attachment-relationship characteristics that form the theoretical basis of Emotionally Focused Therapy to also be seen in marriageromantic relationships. Afterward, Hazan and Shaver (1987) aimed to reveal the adult romantic attachment features with their study conducted on 1,200 people. The results from that research revealed adult romantic attachment and child-caregiver attachment to show similar characteristics. Themes such as the search for closeness, the anxiety of being abandoned, and the need for peace are among these similar features. In the case of separation and loss, the stress response (Hazan \& Shaver, 1987) and the effect the presence of secure attachment figures has on the ability to cope with problems (Bloom, Asher, \& White, 1978) are other similar features. The unique features of romantic attachment are: spouses being a reliable support for one another (Zeifman \& Hazan, 2008), communicating for maintaining spousal bonds (Bretherton, 1990), spousal emotion regulation in possible stressful and tense situations (Pietromonaco, Greenwood, \& Barrett, 2004), and using problem-solving methods in conflict situations (Pistole, 1989).

Emotionally focused couples therapy tries to create safer attachment styles in place of the insecure attachment styles that occur in the close relationships spouses established(Gladding, 2015). Emotionally focused therapy emphasizes the importance of the factors of emotional accessibility and emotional sensitivity in forming a secure attachment relationship between couples (Johnson, 2004). Emotional accessibility and sensitivity means that when one partner experiences stress, the other partner both emotionally and physically supports the other (Landau-North, 2006). Therefore, when one spouse is inaccessible to the other or indifferent, an insecure attachment relationship arises between the spouses (Johnson \& Whiffen, 1999).

God attachment, like romantic attachment, is another type of adult attachment (Roberts, 2017). Stating one's thoughts about God and religion to be related to one's attachment process, Kirkpatrick (1998) stated that people with secure God attachment 
feel love, acceptance, and forgiveness from God. The more positively one sees God and the more one thinks and feels God to consider them positively, the more one's positive view of self and others changes and improves (Roberts, 2017). Spiritual attachment is used as a way of dealing with problems for those who seek a safe and peaceful life; establishing a secure spiritual bond with God/the Sacred also allows people to deal more effectively with the problems they face in their lives (Pickard \& Nelson-Becker, 2011).

Kirkpatrick and Shaver (1990) stated one's formed perception of God to depend on both the attachment relationships one established as a child and the parents' religious beliefs. Similar to the parent-child attachment relationship, the Godattachment relationship, like other attachment relationships, also has features that are experienced such as the presence of a peaceful safe environment, the search for intimacy, and feeling stress when moving away from the attachment figure (Grangvist \& Hagekull, 1999, as cited in Roberts, 2017). Together with commitment to religion and positive images of God being found in secure attachment to God, physical and mental health are also said to be related to secure attachment to God (Rowatt \& Kirkpatrick, 2002). Apart from this, the insecure attachment relationship established with an insecure parent in childhood can be corrected in adulthood with a secure attachment to God (Kirkpatrick, 1998). On the other hand, adults who experience insecure attachment to God experience depression, loneliness, anxiety, and physical discomfort more pronouncedly than those who experience secure attachment to God (Rowatt \& Kirkpatrick, 2002).

Research shows an increasing number of clients who receive counseling service to have stated having existing connections with God or supreme power in the counseling process. A semi-structured interview form has been developed for psychological counselors and specifically designed to examine clients' spiritual and religious backgrounds of clients with a focus on attachment theory. Using this interview form, which is known as Spiritual Attachment History (Dansby et al., 2017), the study aims to obtain an auxiliary tool for clients to convey what they want to tell. Sample items taken from this 19-item evaluation tool are given below.

- What brought you hope when you were young? (Item 4)

- Were there any people who you would go to for comfort during spiritually difficult times? (Item 6)

- Can you tell me about any times when you've been able to be vulnerable and find comfort with God/High Power? (Item 15)

- How will I know when you begin to trust me and this therapy process, both spiritually and otherwise? Can you tell me when you start to feel unsafe here? (Item 19) 
The Spiritual Attachment History examines the clients' spiritual lives within the framework of their attachment histories, which are basically based on the insecure attachment relationships they establish with God and others (Dansby et al., 2017).

\section{Using the Emotionally Focused Therapy Approach While Working with Christian Couples: Working with Triangles}

The emotionally focused therapy approach shows vital, humanistic, and structural systemic features. The structural systemic part of the therapy aims to break the negative communication cycle present in couples' relationship and to reveal new forms of relating (Johnson et al., 2005).

Christians develop a deep sense of identity through their marriage and regard it as something sacred. The stress they see in their marriage also shows a religious and spiritual feature for them (Rizkallah \& Hudson, 2019). Couples use triangles to deal with stress and anxiety (Minuchin, 1974). Triangles are used to indicate systems in which three people are in a dynamic equilibrium. The most important factors impacting the effectiveness of this system are anxiety and stress. If the levels of anxiety and stress in bilateral relations are low, the relationship between these two people will also be calm. However, keeping stress and anxiety levels low at all times is difficult. If stress and anxiety levels increase, the relationship between the two people gets affected. Deteriorating balance in a relationship is followed by including a third person in the relationship. Thus, existing stress and anxiety will attempt to be reduced through division (Kerr \& Bowen, 1988).

Emotionally focused couples therapy aims to reveal and correct negative relationships that prevent spouses from having a trusting and peaceful relationship (Johnson, 2004). In this respect, an in-depth study of spirituality is a basic intervention for Christian couples who have created triangles using God (Rizkallah \& Hudson, 2019). The triangle types created in structural family therapies (coalition, displacement, and substitution) show the relationships that each partner has established with God in the established marriage relationship and reveals how the triangles formed with God are realized (Butler \& Harper, 1994).

In the case of the coalition triangle, each spouse thinks that they are right in the eyes of God and blame the other; they create situations to support these thoughts and reveal them in therapy (Butler \& Harper, 1994). This situation forces the couples apart and causes them to avoid solving the problem. For example, couples have a dispute about which school their daughters should attend, and the father may indicate that he should make this decision and that God leaves it to him. As seen in this example, it is usual for couples to avoid listening to each other in such an environment and to talk about things other than solving the problem. The spouse in the role of father 
established a coalition with God and went to exclude his wife directly because his wife disagreed with him (Rizkallah \& Hudson, 2019).

In the case of displacement triangle, couples tend to attribute their existing stress and anxiety to God. These couples, who tend to see God as the reason for the negativity in their relationship, throw the blame on God as a third person. If the spouses' relationships with God are weak, both partners' unite against God and end their emotional loyalty to God (Butler \& Harper, 1994).

In the case of a substitution triangle, one or both of the spouses go to establish a close relationship with God instead of each other. In other words, in the case of a disagreement or divergence, the spouses turn to God and try to find the sense of intimacy they seek in the relationship they have established with God, aiming to decrease their anxiety levels in this way (Butler \& Harper, 1994). As can be seen, the created triangles prevent spouses from taking responsibility; the techniques used in therapy for dealing with the problem in the marriage structure aim to ensure that God is heard as an impartial voice (Butler \& Harper, 1994).

In the context of the emotionally focused couples therapy approach, interventions related to triangle formation aim to reveal partners' basic feelings and to break the cycle in which negative relationships are experienced. The interventions used are: validation, evocative questions, heightening, empathic conjecture, tracking and reflecting, and reframing problems in terms of content and cycle (Rizkallah \& Hudson, 2019).

\section{Case Example 1}

Some therapy processes that include triangle formation processes and intervention methods within the framework of the emotionally focused couples therapy approach are described in Table 1 (For more detailed information on this issue, see Rizkallah \& Hudson, 2019, pp. 224-225).

In the later stages of the therapy process, the focus is on the fear of denial, the feeling felt underneath everything. In the course of therapy, God is not excluded. They were allowed to see how Jeff and Wendy had maintained their negative relationship cycle using God. Jeff and Wendy were able to see their basic attachment needs and feelings, and after their emotions changed, they could establish safer attachment relationships with both God and each other (Rizkallah \& Hudson, 2019). Revealing the emotion felt under the events and situations is one of the main objectives of emotionally focused therapy. The impact spiritual elements have on emotions felt underneath everything should be examined in the counseling process. 
Table 1.

Example of Emotionally Focused Couples Therapy Case for Triangle Building Processes

Problem: Wendy and Jeff have been married for 5 years. They have no children. Jeff has been working hard at a law firm for the past six months. Wendy works a part-time job. Both partners state that God has a very important place in their marriage and say that they continue going to church regularly. Wendy complains about Jeff's hard work and spending most of his time off work at church events. Jeff, on the other hand, states that a Christian wife should support her husband in attending such church activities and wants to be understood. Wendy thinks she is not understood by her husband and states that speaking is unnecessary.

Counseling Process: The therapist, by asking evocative questions, asked Wendy how she felt when she said she did not think she was understood by her husband. Wendy stated that she felt lonely but returned to God and prayed that she would not feel that way. The therapist asked for validation, saying "When you are suffering and you have no one to turn to, you want to find understanding and peace by turning to God." Wendy stated that this situation caused her a lot of pain and she felt suppressed. The therapist heightened at this stage and said, "You seem to say that you feel suppressed by both your husband and God. You feel so much pressure that you can't handle it." The therapist then turned to Jeff and asked a evocative question, saying "What did you feel when Wendy said she felt like she was under intense pressure?" Jeff stated that this was not what he wanted, but he did not know what he should do to make Wendy to listen to him. The therapist followed up with a reflective statement and question: "You feel anxious and unsupported, Jeff. So, you want to be with God and make Wendy to listen to you. Is this true?" Jeff stated that he was very anxious and at the same time very frustrated when Wendy did not listen to him; he stated that he was happy due to the fact that Wendy was a good Christian, but this was not enough for their relationship. The therapist used the empathic conjecture technique and told Jeff, "You feel that you are worthless in the relationship and it is embarrassing to ask something from your partner and tell her you need it. That's why you want to take God on your side." The therapist heightened and turned to Jeff, "If you demand attention from your partner, you get uneasy because you think your partner will not respond to you or she ignores you." Then the therapist turned to Wendy and said, "You heard that it's a very difficult situation for Jeff to ask to pay attention, and that he thought you would not respond even if he asked. How did it make you feel?" the therapist asked. The therapist turned to Wendy who was upset and stated empathic conjecture by saying "You may have made mistakes. As if there is a fear here." Wendy stated that she was afraid that she could not make her husband happy. The therapist reframed the problem by saying "Wendy, you're afraid of it, thinking that Jeff is going to reject you when Jeff is not at home because he is busy. That's why you turn to God for peace. When Jeff comes home, he becomes anxious and frustrated, thinking that he cannot communicate with you. This whole cycle is constantly refreshing itself. Is this correct? You both want to take God with you and seek help from Him. However, you are getting further away from each other in the process" (Rizkallah \& Hudson, 2019, pp.224-225).

\section{Emotionally Focused Couples Therapy and Faith-Sensitive Approach}

Studies conducted on the relationship between marriage and religiosity reveal positive and negative relationships to exist between divinity and marital satisfaction (Mahoney et al., 1999). Religious factors are also stated to protect against infidelity (Atkins \& Kessel, 2008) and divorce (Booth, Johnson, Branaman, \& Sicca, 1995).

Religious couples share their spiritual and religious teachings, while talking about marital relationships and share the issue by sanctifying the marriage (Mahoney et al., 1999). According to Christian beliefs, marriage is seen as a gift from God. The promises given in the marriage alliance refer to the couples' commitment both to each other and to God (Bruggemann, 1979). The blessing of marriage immediately manifests itself in the marriages because it completely relates to the activities and the meaning attributed to the relationship. Also, because marriages are considered sacred, couples can invest much more energy to protect it. These couples interpret their feelings by expressing them spiritually. Their love, loyalty, gratitude, and 
admiration are always based on a spiritual perspective. For example, if a husband is pleased with how his wife approaches and listens to him, he tends to connect this to his wife's piety and is grateful to both his wife and God. These couples also pray to God for their marriage to become stronger. The therapist should understand the meaning that couples give to their marriages and should take into account that these events are actually done according to their beliefs (Furrow et al., 2011).

\section{Case Example 2}

Table 2 below describes how the blessing of marriage is examined from the perspective of emotionally focused therapy with an example of the therapy performed by Brent Bradley (See Furrow et al., 2011, pp. 357-366).

Table 2.

Example of the Case of Consecrating the Blessed Marriage in Terms of Emotionally Focused Therapy

Problem: Both partners stated that religion and faith have an important place in both their beliefs and marriage relations. The husband thinks his wife was sent to him by God in response to his prayers. However, despite thinking like this, when he has a disagreement with her, his reaction to the situation is in the form of yelling and getting angry. However, when he shouts at her, he thinks he is not worthy of her or God and feels guilty; he is afraid his wife will leave him on his own. It turned out the husband suffered deeply due to having a negative self-image and a sense of loneliness. The feeling of anger expressed by the husband in the communication cycle the spouses experienced was actually the reflection of the external fear of being alone. The basic emotion must be found, and this emotion must be felt.

Counseling Process: The therapist asked the spouses to say face to face what they felt about each other to establish a close relationship and improve their sensitivity towards each other. The husband was able to express the feeling of loneliness he felt when they fought and the fearful feeling of being abandoned. In response, the female partner stated these feelings her husband felt had caused sadness in her and that she felt more supportive of her husband now. The therapist wanted to highlight the risks taken by gaining awareness of emotions and to emphasize that the sense of intimacy they feel has a spiritual element. The couple stated that it was God's will to reveal the awareness that is at the bottom of this sacred place in this way, and it makes them happy to have done so. In the next process, the husband realized the need for emotional intimacy he must connect to and learned to express it when he wanted to hear that he was loved. Thus, the therapist used their sanctified spiritual understanding as a resource for the couple's union (Furrow et al., 2011, pp. 357-366).

The aim of emotionally focused couples therapy is to help couples by using emotions and emotional experiences to meet couples' need for closeness, attachment, and trust (Johnson, 2004). The therapist tried to reveal the couple's negative behavior and communication patterns by benefitting from their emotional experiences. The aim was to have the spouses become more aware of the cycle when quarrelling and the subsequent feeling of separation leads to the husband getting angry (Furrow et al., 2011). In addition, emotions appear as the reason for the negative relationship and communication cycle the spouses experience; for this reason, the therapist tried to reveal the feelings the spouses were unaware of or don't accept and to help provide loyalty between the spouses by calling on the need for closeness, communication, and trust (Johnson, 2004). The therapy revealed need for intimacy to manifest through the fear of being abandoned. By releasing this feeling, the spouses heard and felt each other. Thus, feeling closeness, which is an attachment need, was able to occur (Furrow et al., 2011). 


\section{Emotionally Focused Couples Therapy and Religious Inter-Spousal Conflicts}

Pargament and Mahoney (2005) stated that sanctifying marriage through religion is both a strength and weakness. The example case in Table 2 shows how marriage is strengthened by using religious elements in marriage. However, the privileged place of religion in marriage cannot always be used as a factor in reducing and eliminating problems. In some cases, religious beliefs and practices are also known to have a possible negative effect on the marriage relationship.

The tension experienced in stressful situations will have a much greater result than tension experienced in a normal marriage because marriage also has great meaning. Couples with different degrees of spiritual and religious beliefs and practices also have different perceptions of love and marriage (Furrow et al., 2011). Religious disagreements affect the therapy process, and the information that the therapist acquires about the clients' religious background enables further analysis of the problem. For example, how bereavement, anger, rage, religious devotion, relationship with God, and devotion to marriage are examined depends on the presence of the therapeutic environment the therapist creates (Davidovsky, 2018).

\section{Case Example 3}

The case example in Table 3 states that a couple's disagreements on religious issues has been examined from the perspective of emotionally focused therapy through the religious elements of Orthodox Judaism, the obtained information can however be used for all religions (For more detailed information, see Davidovsky, 2018, pp. 356-360).

Table 3.

A Case Study on the Use of Emotionally Focused Couples Therapy in Religious Conflicts

Jacob is 35 years old and Illana is 25 . Illana grew up in an ultra-Orthodox Jewish community and regularly attended religious school. During her university education, she went to a secular school at the request of her mother. She had a problematic adolescence with severe eating disorders. Over time, Illana moved closer from a strict and narrow view of Judaism to a broader view. Despite this situation, she still considers herself to be Orthodox and tries to act in accordance with all Judaic practices and rules. Jacob grew up in a secular and liberal home with few rules. As Jacob passed into adulthood, he began to feel close to the beliefs and practices of Hasidic Judaism, where rules and practices are harsh and strict. Illana and Jacob have serious differences in terms of religious practices and applications. Before getting married, Illana and Jacob had experienced difficulties due to the differences in their religious views. However, Illana decided to marry because she thought that these differences would not cause serious problems. After being married for 10 months, they had a daughter. A few months later, she became pregnant with twins again yet she had a miscarriage and had to abort pregnancy, which is when she started therapy. Jacob stated that Illana was disappointed because she acted distant and negligent towards both herself and her daughter. Jacob stated that Illana didn't sit at the table to eat with him, that she showed irregular eating behaviors, and that Illana's eating disorder may have reappeared. Jacob and Illana stated that the problem is only due to her eating disorder and they want to solve it as soon as possible (Davidovsky, 2018, pp. 356-360).

The emotionally focused therapy approach consists of three stages (Johnson, 2004). The therapist establishes a therapeutic association and understands the main 
attachment problems in the first stage by determining the negative relationship cycle and understanding the basic underlying emotions that occur. The problematic state of the problem should be regulated together with the negative relationship cycle, attachment needs, and actual underlying emotions (Johnson, 2004).

In the first stage of the sample case, which was dealt with from the perspective of emotionally focused couples therapy; efforts were made to define Jacob and Illana's emotions and to have them be sensitive and listen to each other. Awareness emerged on the point of Illana's eating behaviors deteriorating as an expression of anger towards Jacob. Because Jacob is a professional chef, he makes every kitchen-related decision, and this annoys Illana, causing her to get angry with Jacob (Davidovsky, 2018). Structural systemic interventions are also used in emotionally focused therapy (Johnson, 2004). In this respect, in order to change the negative relationship between the couple, they were given an assignment to try at home. Jacob will not cook, Illana will take on this responsibility, and Illana will have dinner with Jacob. Jacob and Illana studied the emotional experiences underlying their relationship. By refusing to sit together at the dining table or eat the food her husband had prepared, Illana was expressing her feeling of anger out loud; she determined the underlying issues in the process that followed (Davidovsky, 2018).

The emotionally focused therapy approach is a combination of humanistic, vital, and systemic approaches. The existence of a humanistic point of view states talking about emotions in therapy to be important, and the basic condition for unraveling emotions is to provide a reassuring therapeutic environment (Johnson et al., 2005). The therapist's self-disclosures and the fact that Jacob and his wife are Jewish provided a safe environment. The therapist wanted to use Jacob's relationship with his Rabbi in terms of religion, and collaborated with the Rabbi. Because the Rabbi's views on marriage were in line with the idea that peace would surely come as a result of both parties making concessions, this motivated Jacob to take steps to resolve his arguments with Illana (Davidovsky, 2018).

In emotionally focused therapy, spouses should express their fears and attachment needs clearly (Johnson \& Denton, 2002). The therapist made the spouses listen, hear, and understand each other and mentioned the religious conflicts between the couple. He talked to Jacob about Illana's discomfort due to his strict adherence to religious rules, and Jacob expressed the need for attachment by stating that he felt lonely. Jacob approached Illana's needs and responded with empathy (Davidovsky, 2018).

In the second phase of the emotionally focused therapy approach, each side gains awareness of their attachment needs and emotions. Couples mutually accept their experiences and create reorganized relationships. Lastly, they reconstruct emotional unity by clearly stating their needs and wishes (Johnson, 2004). In this case, Illana at 
times expressed her anger unstably. She was able to express her pain when she saw that Jacob heard and responded to her. Jacob expressed his love for Illana and asked Illana to understand the need to act in accordance with Judaic rules. Illana also stated her need to grieve for their lost babies (Davidovsky, 2018).

In the emotionally focused therapy approach, the third stage consists of two steps: finding new solutions to problem situations and regulating attachment behaviors (Johnson, 2004). Jacob and Illana stated that they will strive to continue their marriage as best they can. However, as time went on, Jacob's extreme strict understanding of religion made Illana feel more stuck, and the couple ended up divorcing sometime after the end of therapy (Davidovsky, 2018).

\section{Conclusion}

The emotionally focused couples therapy approach focuses on the relationship, communication structures, emotional experiences, emotions, and attachment needs and how these needs are expressed (Johnson, 2004; Rizkallah \& Hudson, 2019). It primarily aims to reveal unhealthy communication cycles during the therapy process (Rizkallah \& Hudson, 2019). Afterward, the couples are encouraged to express their emotional experiences and emotions, attempting to reach and express the basic underlying emotions so that the couples can hear and feel each other (Johnson, 2004).

Spirituality and religion show themselves both in a couple's individual lives and during the marriage (Walsh, 2012). Therapists who practic emotionally focused therapy transform the insecure attachment relationships between a couple into new and healthy attachment relationships using spirituality (Dansby et al., 2017). While couples therapists cannot ignore the religious and spiritual content offered to them while working with couples, they want to integrate these into their psychotherapy practices (Furrow et al., 2011).

In this article, we have attempted to explain the relationship the emotionally focused couples therapy approach has with religion and spirituality and have given case studies on how religious-spiritual elements can be used in the therapy process. We have studied he emotionally focused couples therapy approach in the context of religious couples. In this respect, the effects of religious and spiritual elements first were shown to strengthen the marriage; afterwards, we have attempted to explain the harm that religious conflicts between couples may cause the marriage relationship using case examples. Finally, we have focused on how religious items can be used in the therapy process to cope with child loss, which is traumatic in terms of marriage.

This article discusses the emotionally focused therapy approach, one of commonly used approaches in the field of couples and family therapies today, and how the process can be directed together with the spiritual elements that can be encountered in the 
therapy process. Attachment relationships, the underlying feelings, and the attachment problems clients with different religious and spiritual beliefs experience occur both in relation to the religious and spiritual supreme power couples adopt individually and in their relations in this therapy approach, which aims at exposing these emotions. As can be seen, although publications are found about Christianity and Judaism among the studies conducted in the field of religion and spirituality using the emotionally focused couples therapy approach, studies that include Islamic elements and themes in the therapy process are needed. Understanding how and in which ways Islamic elements (e.g., sunnah, hadiths, scripture, religious stories) can be used while working with the underlying feelings is important. This article has provided brief information about the emotionally focused therapy approach and then attempted to show how the process is maintained using spiritual elements. The literature created on the basis of Christianity and Judaism religious and spiritual beliefs shows no therapeutic approach to have been combined with Islamic beliefs. This article, which was prepared for this purpose, intends to raise awareness to reveal this deficiency and serve as an example for psychological counselors and psychologists on how spiritual elements can be integrated into therapy.

\section{References}

Allen, J. (2008). The attachment system in adolescence. In J. Cassidy \& P. Shaver (Eds.), Handbook of attachment: Theory, research and clinical applications (2nd ed., pp. 419-435). New York, NY: Guilford Press.

Aponte, H. J. (2002). Spirituality: The heart of therapy. Journal of Family Psychotherapy, 13(1/2), 13-27. doi:10.1300/J085v13n01_02.

Atkins, D.C. \& Kessel, D. E. (2008). Religiousness and infidelity: Attendance, but not faith and prayer, predict marital fidelity. Journal of Marriage and Family, 70, 407- 418.

Bloom, B. L., Asher, S. J., \& White, S. W. (1978). Marital disruption as a stressor: a review and analysis. Psychological Bulletin, 85(4), 867- 894.

Booth, A., Johnson, D. R., Branaman, A., \& Sicca, A. (1995). Belief and behavior: Does religion matter in today's marriage? Journal of Marriage and the Family, 57, 661-671.

Bowlby, J. (1969). Attachment and loss (Vol. 1). New York: Basic Books. doi:10.2307/2798963.

Bowlby, J. (1973). Attachment and loss: Separation anxiety and anger (Vol. 2). New York: Basic Books. doi:10.1192/bjp.123.5.600-a.

Bretherton, I. (1990). Communication patterns, internal working models, and the intergenerational transmission of attachment relationships. Infant Mental Health Journal, 11(3), 237-252.

Bruggemann, W. (1979). Covenanting as human vocation: A discussion of the relation of Bible and pastoral care. Interpretation: A Journal of Bible and Theology, 33, 115-129.

Butler, M. H., \& Harper, J. M. (1994). The divine triangle: God in the marital system of religious couples. Family Process, 33(3), 277-286. doi:10.1111/j.1545-5300.1994.00277.x

Dansby, R. A., Hayes, N. D., \& Schleiden, C. (2017). A guide for assessing clients' attachment to the sacred: The spiritual attachment history. Contemporary Family Therapy, 39(1), 1-11. doi: 10.1007/s10591-017-9402-5 
Davidovsky, G. C. (2018). The Orthodox Jewish couple in therapy: Addressing religious conflict and confronting the divine elephant in the room. Clinical Social Work Journal, 47, 353-362. doi: 10.1007/s10615-018-0697-y.

Furrow, J. L., Johnson, S. M., Bradley, B., \& Amodeo, J. (2011). Spirituality and emotionally focused couple therapy: Exploring common ground. In J.L. Furrow, S. M. Johnson, \& B. A. Bradley (Eds.), The emotionally focused casebook: New directions in treating couples (pp. 343372). New York: Routledge.

Gladding, S. T. (2015). Aile terapisi Tarih, Kuram ve Uygulamaları (Çev. İ.Keklik \& İ. Yıldırım), (5. Bask1). Ankara: Türk Psikolojik Danışma ve Rehberlik Derneği.

Gurman, A. S., \& Fraenkel, P. (2002). The history of couple therapy: A millennial review. Family Process, 41(2), 199-260.

Hazan, C., \& Shaver, P. (1987). Romantic love conceptualized as an attachment process. Journal of Personality and Social Psychology, 52(3), 511-524.

Johnson, S. M. (2004). The practice of emotionally focused coupled therapy (2nd ed.). New York: Brunner/ Routledge.

Johnson, S. M. (2017). An emotionally focused approach to sex therapy. In Z. Peterson (Ed.), The Wiley handbook of sex therapy (pp. 250-266). New York: Wiley.

Johnson, S. M. (2019). Attachment theory in practice: Emotionally focused therapy (EFT) with individuals, couples, and families. New York: Guilford Press.

Johnson, S., Bradley, B., Furrow, J., Lee, A., Palmer, G., Tilley, D., \& Woolley, S. R. (2005). Becoming an EFT therapist: The workbook. New York: Brunner/ Routledge.

Johnson, S. M., \& Denton, W. (2002). Emotionally focused couple therapy: Creating secure connections. In A. S. Gurman (Ed.), The clinical handbook of couple therapy (3rd ed., pp. 221250). New York: Guildford Press.

Johnson, S. M., \& Greenberg, L. S. (1985). Emotionally focused couples therapy: An outcome study. Journal of Marital and Family Therapy, 11(3), 313-317. doi:10.1111/j.1752-0606.1985.tb00624.x

Johnson, S. M., \& Whiffen, V. (1999). Made to measure: Adapting emotionally focused therapy to partners' attachment styles. Journal of Clinical Psychology, Science and Practice, 6, 366-381.

Kaya Balkan, İ. (2009). Bağlanma stillerinin evlilik ilişkisi üzerindeki etkisi (Unpublished Doctoral Dissertation). İstanbul Üniversitesi Sosyal Bilimler Enstitüsü, İstanbul.

Kerr, M. E. \& Bowen, M. (1988). Family evaluation: An approach based on Bowen theory. New York: W. W. Norton \& Company.

Kirkpatrick, L. (1998). God as a substitute attachment figure: A longitudinal study of adult attachment style and religious change in college students. Personality and Social Psychology Bulletin, 24(9), 961-973. doi:10.1177/0146167298249004

Kirkpatrick, L., \& Shaver, P. (1990). Attachment theory and religion: Childhood attachments, religious beliefs, and conversion. Journal for the Scientific Study of Religion, 29(3), 315-334.

Landau-North, M. (2006). Exploring forgiveness as a key therapeutic process in emotionally focused therapy (Doctoral dissertation). Retrieved from Proquest Dissertations and Theses Global database. (UMI No. 3209197).

Mahoney, A., Pargament, K. I., Jewell, T., Swank, A. B., Scott, E., Emery, E., \& Rye, M. (1999). Marriage and the spiritual realm: The role of proximal and distal religious constructs in marital functioning. Journal of Family Psychology, 12, 321-338. 
Minuchin, S. (1974). Families and family therapy. Cambridge: Harvard University Press.

Pargament, K. I., \& Mahoney, A. (2005). Sacred matters: Sanctification as a vital topic for the psychology of religion. International Journal for the Psychology of Religion, 15, 179-198.

Pickard, J. G., \& Nelson-Becker, H. (2011). Attachment and spiritual coping: Theory and practice with older adults. Journal of Spirituality in Mental Health, 13(2), 138-155. doi:10.1080/1934963 7.2011 .565239

Pietromonaco, P. R., Greenwood, D., \& Barrett, L. F. (2004). Conflict in adult close relationships: An attachment perspective. In W. S. Rholes \& J. A. Simpson (Eds.), Adult Attachment: New Directions and Emerging Issues (pp.267-299). Guilford Press.

Pistole, M. C. (1989). Attachment in adult romantic relationships: Style of conflict resolution and relationship satisfaction. Journal of Social and Personal Relationships, 6(4), 505-510.

Post, B. C., \& Wade, N. G. (2009). Religion and spirituality in psychotherapy: A practice-friendly review of research. Journal of Clinical Psychology, 65(2), 131-146. doi:10.1002/jclp.20563

Rizkallah, N., \& Hudson, E. (2019). Circling the triangle: An EFT approach to working with Christian couples triangulating God. Contemporary Family Therapy, 41, 219- 226. doi: 10.1007/ s10591-019-09496-8.

Roberts, S. (2017). A phenomenological analysis of God attachment, romantic attachment and relationship satisfaction in Christian couples completing an emotionally-focused marital intensive. (Doctoral Dissertation). Retrieved from Proquest Dissertations and Theses Global database. (UMI No. 10638116).

Rowatt, W., \& Kirkpatrick, L. (2002). Two dimensions of attachment to God and their relation to affect, religiosity, and personality constructs. Journal for the Scientific Study of Religion, 41, 637-651.

Simon, G. M. (2004). An examination of the integrative nature of emotionally focused therapy. The Family Journal, 12(3), 254-262.

Walsh, F. (Ed.). (2012). Normal family processes: Growing diversity and complexity. New York: Guilford Press.

Weiss. R.S. (1982). Attachment in adults. In C.M. Parkes \& J. Stevenson-Hiade (Eds.), The Place of Attachment in Human Behavior (pp.171-184). New York: Basic Books.

Zeifman, D., \& Hazan, C. (2008). Pair bonds as attachments: Reevaluating the evidence. In J. Cassidy \& P. R. Shaver (Eds.), Handbook of Attachment: Theroy, Research and Clinical Implications (pp.354-436). New York, NY: Guilford Press. 